(อ)

OPEN ACCESS

\title{
25-year-old man with sudden onset paraplegia
}

\author{
Marco Manieri
}

Emergency Department, Skanes universitetssjukhus Malmo, Malmo, Sweden

\section{Correspondence to \\ Marco Manieri;}

marco.manieri@skane.se

Accepted 25 September 2019

\section{SUMMARY}

A 25-year-old man with Crohn's disease presented to the emergency department with sudden onset bilateral leg pain, paraplegia and loss of anal sphincter tone. CT angiography revealed a massive abdominal aortic thrombosis. Revascularisation surgery was performed promptly, saving most of the abdominal organs, but motor function of the legs was not restored. No coagulation disorder was identified, and no other underlying cause for thrombosis was found. It was speculated that it may be related to the patient's underlying Crohn's disease.

\section{BACKGROUND}

Aortic thrombosis is a rare disease, even more so in a young athlete. There is a suspected connection to inflammatory bowel disease (IBD) which may be of interest to future researchers.

\section{CASE PRESENTATION}

A 25-year-old man presented to the emergency department with sudden onset paraplegia and pain in the lower extremities. His medical history included Crohn's disease, managed with sulfasalazine. He was otherwise healthy, worked as a tradesman, and was competing in fitness championships. There was no history of trauma to the back or abdomen. Earlier in the morning, while lifting a $10 \mathrm{~kg}$ object at work, he experienced sudden onset of bilateral leg pain and felt the urge to defecate. While in the bathroom, he lost power in his lower extremities and was found on the floor by his coworkers. Vital signs were stable upon ambulance crew arrival. The patient presented with abdominal and bilateral leg pain in addition to numbness and paralysis of the legs. He had faecal incontinence and had soiled his clothes and the floor. During ambulance transport, he received intravenous crystalloid fluids, ondansetron and a total of $25 \mathrm{mg}$ of intravenous morphine.

On arrival to the resuscitation room at Skåne University Hospital in Malmö, the patient was still complaining of pain, now primarily localised to the perianal region, and persistent paraplegia. His vital signs were within normal range, except blood pressure that was elevated at $180 / 90 \mathrm{~mm} \mathrm{Hg}$. His legs were pale, cold and numb with flaccid paralysis. Femoral and distal peripheral pulses were impalpable. Sensory loss extended distally from the umbilical level, whereas examination above the umbilical level was normal. Bedside ultrasonography revealed no free intra-abdominal fluid and the aorta appeared normal. On log-rolling, there was no sign of trauma or midline tenderness on

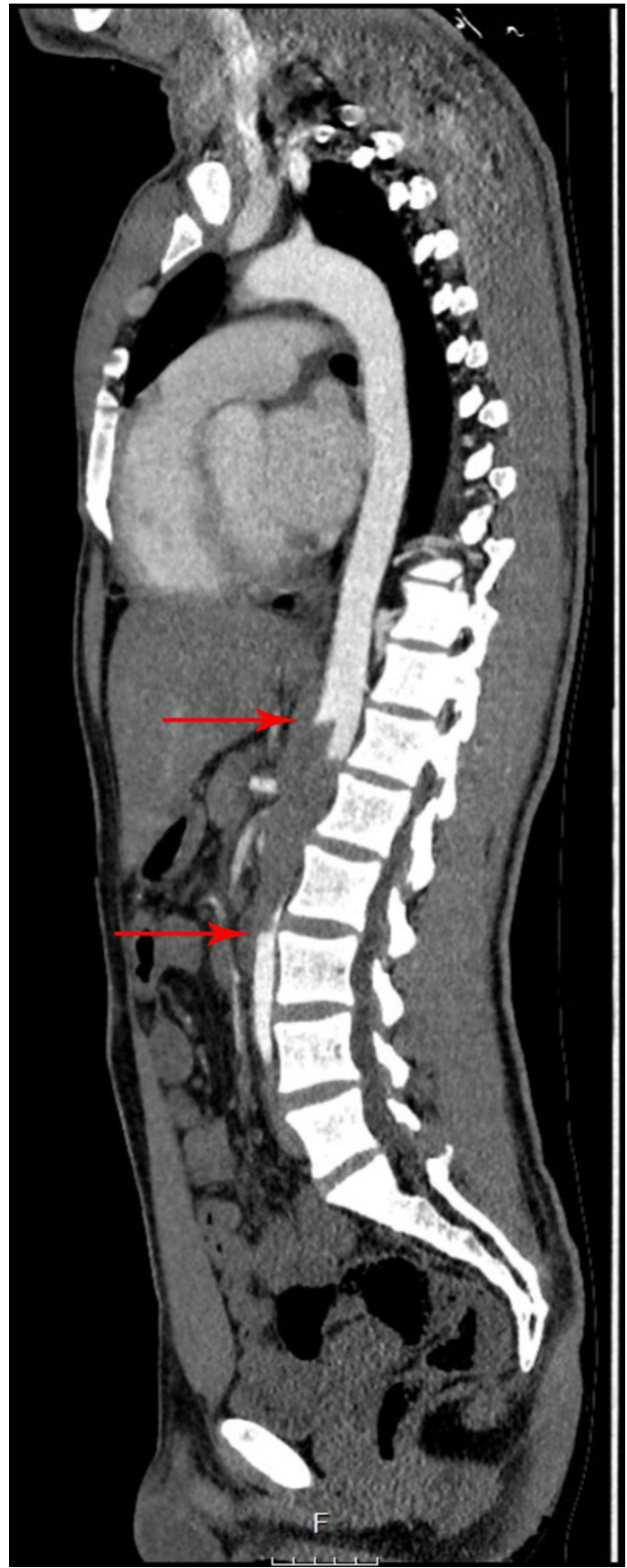

Figure 1 CT angiography sagittal image. Red arrows point to the proximal and distal end of the thrombus in the aorta. There is passage of contrast medium, but the distal diameter is less due to decreased flow.

palpation of the spine. Rectal examination revealed total loss of sphincter tone and sensation in the perianal area. Bedside arterial blood gas showed 


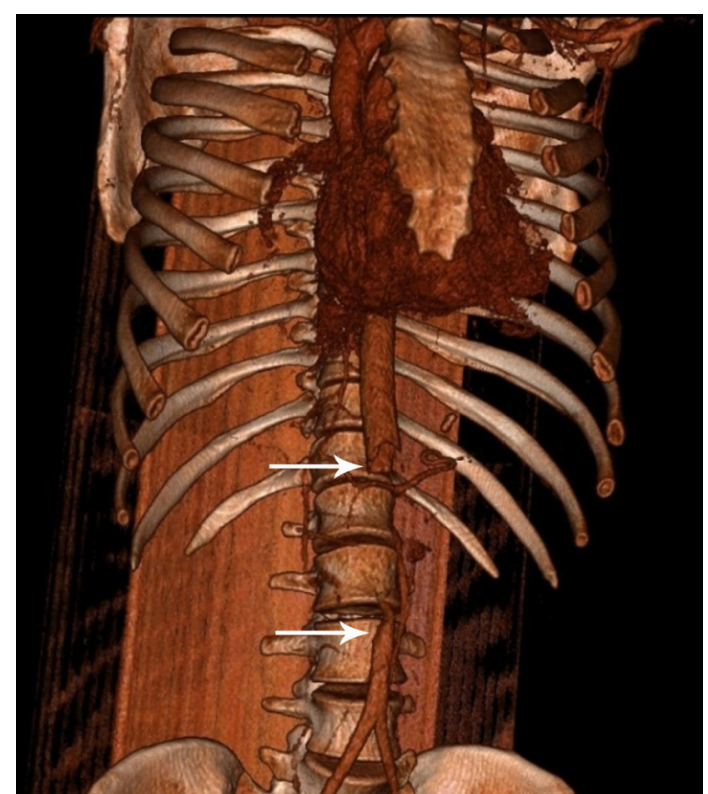

Figure $23 \mathrm{D}$ reconstruction of $\mathrm{CT}$ angiography. White arrows point to the proximal and distal end of the thrombus.

metabolic acidosis with $\mathrm{pH} 7.2$, base excess $-13 \mathrm{mmol} / \mathrm{L}$, lactate $6.2 \mathrm{mmol} / \mathrm{L}$, an elevated creatinine at $155 \mu \mathrm{mol} / \mathrm{L}$ and otherwise unremarkable. More analgesia was given.

\section{INVESTIGATIONS}

The vascular surgery consultant was summoned and the patient was expedited to the CT scanner for imaging. CT angiography of the whole aorta revealed aortic thrombosis, extending from the level of the diaphragm to the aortic bifurcation (figures 1 and 2). No signs of atherosclerosis were visible.

\section{TREATMENT}

The patient was transferred directly to the operating theatre where emergency hybrid surgery was performed. Open exploration revealed extensive visceral ischaemia. The occluded arterial branches were clamped distally in an effort to avoid further embolisation. Thereafter the following endovascular interventions were performed: thrombectomy and stenting of the right renal artery, superior mesenteric artery and distal aorta. There was no macroscopic anomaly of the aorta that the surgeons could identify. On reperfusion, there was massive swelling of both legs requiring several fasciotomies. The patient was transferred to the intensive care unit (ICU) where he remained intubated for 2 days. Second-look surgery was performed 24 hours after the first intervention and revealed viable abdominal organs except for the gallbladder, which was removed. During the patient's 58-day ICU stay, multiple complications occurred, including local and systemic infections, renal failure secondary to rhabdomyolysis and reactive depression with profound anxiety.

\section{OUTCOME AND FOLLOW-UP}

After transfer from the ICU, a further month of admission to the vascular surgery ward was followed by another 3.5 months of inpatient spinal rehabilitation before discharge. The patient had regained some sensory function of the lower extremities but, unfortunately, he remained wheelchair-dependent.

The patient was investigated by the coagulation department, but no coagulation disorder was identified and the underlying reason for developing this massive aortic thrombosis remains a mystery.

\section{Learning points}

- When clinical findings point strongly in one direction, this must be pursued, however uncommon the diagnosis. The combination of ischaemic lower extremities and spinal ischaemia (paralysis and sensory loss) is strongly suggestive of an abdominal aortic occlusion.

- Inflammatory bowel disease is an independent risk factor for thromboembolic disease.

- Abdominal aortic thrombosis is a true vascular emergency and, even when handled in a timely fashion, patients are at a high risk of severe morbidity and mortality.

\section{DISCUSSION}

Aortic thrombosis in an otherwise normal aorta is a rare occurrence. $^{12}$

A link between IBD and thromboembolism has been established, but primarily in the venous system. ${ }^{3}$ A link between IBD and aortic thromboembolism has also been suggested. ${ }^{4}$ One can only speculate that this case is related to IBD as no actual evidence to support this explanation is available.

The patient was previously engaged in fitness competitions (akin to body building), and the issue of anabolic steroid use was raised on multiple occasions, something that the patient denied decidedly, and continues to deny to this day. He was also tested negative for illicit substances in conjunction with a competition only 6 months prior to the incident.

In previously published cases of aortic thrombosis, the outcomes range from full recovery to death. Azzarone et al reported full recovery in a patient with an operative approach similar to this case, ${ }^{2}$ while Matsuoka and Hashizume reported a case where the patient suffered cardiopulmonary arrest while waiting for the CT to be performed. ${ }^{5}$ The patient described here was diagnosed promptly and treated in a timely fashion, but nonetheless suffered severe complications. This illustrates and stresses the severity of this rare condition as a true vascular emergency.

Contributors MM: planned, conducted and reported.

Funding The authors have not declared a specific grant for this research from any funding agency in the public, commercial or not-for-profit sectors.

Competing interests None declared.

Patient consent for publication Obtained.

Provenance and peer review Not commissioned; externally peer reviewed.

Open access This is an open access article distributed in accordance with the Creative Commons Attribution Non Commercial (CC BY-NC 4.0) license, which permits others to distribute, remix, adapt, build upon this work non-commercially, and license their derivative works on different terms, provided the original work is properly cited and the use is non-commercial. See: http://creativecommons.org/ licenses/by-nc/4.0/.

\section{REFERENCES}

1 Fayad ZY, Semaan E, Fahoum B, et al. Aortic mural thrombus in the normal or minimally atherosclerotic aorta. Ann Vasc Surg 2013;27:282-90.

2 Azzarone M, De Troia A, lazzolino L, et al. Hybrid treatment of acute abdominal aortic thrombosis presenting with paraplegia. Ann Vasc Surg 2016;33:228.e5-8.

3 Giannotta M, Tapete G, Emmi G, et al. Thrombosis in inflammatory bowel diseases: what's the link? Thromb J 2015;13:14

4 Novacek G, Haumer M, Schima W, et al. Aortic mural thrombi in patients with inflammatory bowel disease: report of two cases and review of the literature. Inflamm Bowel Dis 2004;10:430-5.

5 Matsuoka Y, Hashizume M. Cardiopulmonary arrest caused by acute abdominal aortic thrombosis: a case report. BMJ Case Rep 2009;2009:bcr09.2008.0947. 
Copyright 2019 BMJ Publishing Group. All rights reserved. For permission to reuse any of this content visit https://www.bmj.com/company/products-services/rights-and-licensing/permissions/

BMJ Case Report Fellows may re-use this article for personal use and teaching without any further permission.

Become a Fellow of BMJ Case Reports today and you can:

- Submit as many cases as you like

Enjoy fast sympathetic peer review and rapid publication of accepted articles

Access all the published articles

Re-use any of the published material for personal use and teaching without further permission

Customer Service

If you have any further queries about your subscription, please contact our customer services team on +44 (0) 2071111105 or via email at support@bmj.com.

Visit casereports.bmj.com for more articles like this and to become a Fellow 